\title{
STUDENTS' BULLYING EXPERIENCES AT UNIVERSITY LEVEL
}

\section{Deasyanti*, Fellianti Muzdalifah \\ *Correspondent Author}

Deasyanti

Universitas Negeri Jakarta

Jalan R. Mangun Muka Raya Nomor 11, Rawamangun, Pulo Gadung, Kota

Jakarta Timur, Daerah Khusus Ibukota

Jakarta

Indonesia

Email: deasyanti@unj.ac.id

\section{Fellianti Muzdalifah}

Jalan R. Mangun Muka Raya Nomor 11, Rawamangun, Pulo Gadung, Kota Jakarta Timur, Daerah Khusus Ibukota Jakarta

Indonesia

\begin{abstract}
Bullying in the context of the university is crucial to be studied as the impact of bullying on students' well-being. This paper focuses on the issue of bullying at one university in Jakarta, Indonesia. Using an exploratory study, 305 students responded to the close and open-ended questionnaire. The sample was recruited using cluster random sampling technique. Data were analyzed by the frequency of distribution to describe the extent to which bullying exists in university context. The finding showed that $19.34 \%$ participants have experienced as the bullying victim, 58,36\% as bystanders and $16.72 \%$ as the bully. Direct and verbal bullying is the most frequently used of bullying. The bullying occurred when the students were gathering with their group (57,14\%). Most of the victims of bullying preferred to stay passive and did nothing to ask for help stopping bullying. The percentage of bullying victim in this study was higher than those reported in other existing studies. This finding indicated that bullying in higher education remain an issue. This study implied that the university should stipulate a regulation to to stop bullying as it can adversely affect one's well being in the longterm.
\end{abstract}

Keywords: bullying, victims, bullied, university student

\section{INTRODUCTION}

Bullying has a detrimental effect on an individual's physical, psychological, and social. Various research on bullying aim to find out the impact of bullying, especially on the victim. They are reported to show anxiety, panic attack, agoraphobia, depression, social alienation, and low self-esteem (Copeland et al., 2013; Sinkkonen, H. M. et al., 2014). Furthermore, they also show signs of psychosis symptoms on theier life phase
(Copeland et al., 2013). Bullying is also associated with the self-harm, violent behaviors, and adjustment problems (Bowes, L et al., 2014; McMahon, et al., 2012). Bullying significantly thread psychological well-being for those who were involved in bullying.

Research on bullying has grown rapidly in the last two decades. Most research on bullying has focused on the school context. Whereas studies on this topic in university context are limited (Coleyshaw, 2010). 


\section{4 | PSIKOPEDAGOGIA \\ JURNAL BIMBINGAN DAN KONSELING \\ Vol.10, No.1, June 2021}

Chapel, Casa \& De la Crusz (Marraccini et al., 2015) stated that the frequency of bullying tend to decrease as one grows, yet still continues in adulthood; therefore, bullying case in the higher education tends to be fewer than in other levels of education (Chen \& Huang, 2015; Cowie \& Myers, 2014; Meriläinen et al., 2016). Despite lack of research of bullying in university context, bullying still exists. A survey by NUS in UK showed that $7 \%$ of students had experienced bullying (Coleyshaw, 2010). Meanwhile, a large survey involving Finnish University students by Lappalainen, Meriläinen, Puhakka, \& Sinkkonen (Cowie \& Myers, 2014) found that around $5 \%$ students admitted being bullied either by a fellow student or by a member of university staff. In Indonesia, survey data regarding bullying is still limited, but over the year many of bullying incidents in university context were reported by mass media, such as, bullying in Sekolah Tinggi IImu Pelayaran (STIP) (metro.tempo.co) and in Universitas Islam Indonesia (UII) (regional.kompas.com) in 2017 committed by senior students toward junior students. Since 2000 to 2014, mass media also noted several bullying incidents in higher education. Mass media identified that the bully students were involved in the physical violence, which brings highly detrimental impact or even leads to death.

Considering the discrepancy in number of works on bullying in school and university contexts, it is necessary to investigate bullying in the higher education context. Though the occurence rate is low, compared to cases in high school context, this negative phenomenon cannot be ignored as the this phenomenon cannot be ignored, because in reality this phenomenon may be higher. As stated by Lawson (Coleyshaw, 2010), this phenomenon such as a 'silence' or 'blindspot' that have to be further explored. Using an exploratory approach, this paper describes the extent to which bullying exists in university context, what kinds of bullying and in what situation does it occur, and how do students react when they are being bullied. The implication of this study suggests that the university has to take a formal regulation to stop bullying due to the long-term adverse impact on individual well-being.

\section{RESEARCH METHOD}

This exploratory study was the preliminary stage of the bigger research. The data were collected using bullying questionnaire. The sample was recruited using cluster random sampling technique. All faculties in the university (8 faculties) were involved in this study, but maximum only two study programs of each faculty were selected randomly (total 15 study programs). Then, based on the entry year( i.e., year of 2015, 2016, and 2017), the group of students were selected randomly. Of the 1399 targeted students sample, only 305 students participated voluntary in this study. In other words, the response rate of the targeted participants was $21.80 \%$. The collected data were analyzed by the frequency of distribution to describe the extent to which bullying exists in university context.

\section{RESULT AND DISCUSSION}

Table 1

Gender, Role/Status in Bullying, and Type of Bullying

\begin{tabular}{lcc}
\hline & N & $\%$ \\
\hline Gender & 204 & 66.89 \\
Female & 101 & 33.11 \\
Males & 305 & 100 \\
$\quad$ Total & & \\
Role/Status in Bullying & 51 & 16.72 \\
$\quad$ Bully & 59 & 19.34 \\
$\quad$ Victim & 178 & 58.36 \\
$\quad$ Bystander & & \\
Type of Bullying & 288 & 94.43 \\
$\quad$ Verbal Bullying (Direct) & 6 & 1.96 \\
$\quad$ Physical (Direct) & 11 & 3.61 \\
$\quad$ Social Isolation (Indirect) & & \\
\hline
\end{tabular}

Table 1 shows the results of the analysis of gender, role/status in bullying, and type of bullying. The percentages of the role in bullying in this study are not significantly different from the findings of the Chappell's et al.'s study that $18,5 \%$ students were bullied, $33,4 \%$ as the bystanders, and $13,4 \%$ were the 
bully (Chappell, et al., 2004). On the other hand, a study found that only $6,3 \%$ students who were bullied and $1,7 \%$ were the bully (Giovazolias \& Malikiosi-Loizos, 2016). Wensley \& Campbell (2012) also found that $20,8 \%$ students are the victims, and $5,1 \%$ are the bully. These studies showed that bullying still exists at the university contexts, but the percentages of the person who take a role in bullying are vary among different research.

This study found that regarding to the kind of bullying, most of the students experienced direct bullying including verbal bullying $(94.43 \%)$ and physical bullying (1.89\%); whereas indirect bullying (social isolation) was experienced by $3.77 \%$. This finding is align to the study by Chapell et al. (2004) that verbal bullying is more frequently reported than physical bullying or social bullying. On the other hand, study in Greece found that relational bullying was more frequent that verbal bullying (Giovazolias \& MalikiosiLoizos, 2016). Similar finding was reported by Matsunaga (2010) that in Japan and US students, relational bullying are at the highest frequency, followed by online/cyber bullying, physical bullying, and material/property bullying. In conclusion, the kind of bullying might be similar, but the frequencies of bullying vary depend on the different cultural contexts where the research was conducted.

This current study reported that the frequencies of bullying were experienced everyday by $11.11 \%$ students; several times a week by $24.07 \%$, but most of students have experienced bullying several times a month (64.81\%). This finding was higher than a study by Chapell et al. (2004) that out of 1,025 undergraduate students only $5 \%$ students who had been bullied by students occasionally and $1,1 \%$ very frequently, whereas those who had been bullied by teachers is $4,2 \%$ occasionally and $1,9 \%$ very frequently.

Regarding the victims' reaction to bullying, majority of them chose passive response $(67,27 \%)$ and did not any attempt for help seeking (81.36\%). Closed friend (68.75\%) was the best choice for social supports needed by the victims. This finding is align to Elghazally \& Atallah (2020) that most of the students (91.3\%) tend to keep silence despite they knew the person who took roles in bullying. Unfortunately, lot of participants of this study did not explain the impact of bullying to themselves. Out of 59 participants, only 7 participants who answered this related question, include; no effect at all (2 participants), and the rest of them reported that they feel pesimistic, feeling lazy to go to campus, do not want to communicate with the bully, and experiencing of social inhibition.

The most situation in which the bullying exist include students gathering with peer group $(57,14 \%)$ and in the classroom or in the lecturing session $(22,45 \%)$. In the lecturing session means that the lecturer may being there and took the role as bystander or as the bully. In this survey, students who had seen the lecturer as the bully were 5 students $(8.47$ $\%)$, but almost all students have experienced bullying by fellow students $(91.53 \%)$, and those of them were same year students $(69.77 \%)$. Students do not experience bullying victimization only by their fellow students but also by university personnel (Chapell et al., 2004; Marraccini et al., 2015; Meriläinen et al., 2016) The bullies were not associated to specific gender because either female or male was identified as the bully. However, in Greece, males more involved in victimization and cyberbullying either as the bully or the victims than females (Giovazolias \& MalikiosiLoizos, 2016).

Students who took participant role of bullying as the bystander and the bully reported similar findings to the victims, in regard to: the form of bullying, the person characteristics who take role as the bully, and the situation where the bullying exists. Direct and verbal bullying was the most frequent form of bullying and was committed by the fellow student of the same entry year. Interestingly, situation in the classroom or lecturing session where bullying happened were reported by $38.71 \%$ of bystanders. This finding can be considered that the lecturer took participant role as the bystander. This study found that around $45 \%$ participants involved in bullying in the previous education level, either as the victim or the bully as well. The highest frequency of experience as a 


\title{
26| PSIKOPEDAGOGIA
}

\author{
JURNAL BIMBINGAN DAN KONSELING
}

Vol.10, No.1, June 2021

bullying victim or the bully was when they were in elementary school and middle school. However, this study has not investigated the association between bullying experience in school and in university.

This study revealed percentages of participant role in bullying (i.e., the victims, the bystander and the bully) in university context. Despite they took different participant roles in bullying, $92.74 \%$ out of all participants agree that the phenomenon of bullying in university context can be considered as a crucial problem. Most of them suggested that university should have a strict regulation regarding the consequences for the bully.

Compared to another study using a large survey by NUS (Cowie \& Myers, 2014), the percentages of bullying in this study are higher. This data indicates that self-report technique is sufficient to capture the prevalence of bullying in the context of university. However, because of detail information regarding the effect of bullying is limited, further investigation is needed to reach out more and deep information, such as using interviewing technique.

This study reported that the bully is not related to specific gender. This result supports that both genders engage in all form of bullying, despite males more likely involved in physical or direct bullying (Cosgrove et al., 2017). In this study, physical bullying was committed by one person, but no information about gender of the bully.

Curwen, et al. revealed that around $45 \%$ participants had experience bullying when they were at school, as the victims or as the bully (Cowie \& Myers, 2014). However, this study did not identify whether students previously involved in bullying at school are those who involved bullying in university. This finding confirms previous research that most of bullying victim in the university are those who had the same experience at high school level. In contrast, some studies showed that students who acted as the bully in the high school level were no longer involved in bullying in the next level of education ( Espelage, Hong and Rao, in Holt et al., 2014).
The definition of the term "bullying" remains the object of debate until today.Hence, its definition varies depending on the context of the study (Coleyshaw, 2010). Mynard and Joseph identified that the term of bullying is often used interchangeably to the concept of 'peer victimisation' or 'peer abuse" (Cosgrove et al., 2017). Meanwhile Olweus (2013) defines bullying as aggressive behaviour intended to impose harm or uneasiness upon another person. Coleyshaw (2010) offers simple definition of bullying as a repeated hostile behaviour within an imbalanced power relationship and that behaviour can be physical or psychological.

Despite various definition of bullying and different terms used, most researchers agree to Olweus criteria of bullying that are (1) it is a negative action or aggressive behavior that is intended to harm (2) carried out repeatedly or over time (3) an imbalance power relationship between the agressor and the target (Olweus, 1994). Refers to the first criteria which is intentionality, bullying can be considered as a form of proactive aggresion (in contrast to reactive aggresion) because it can occur without obvious provocation from the targeted person (Olweus, 2013). In addition to the second criteria, Olweus acknowledges that the single instance of harrassment can be categorised as bullying as well because of the impact of it over time (Cornell \& Limber, 2015). It refers to how long the victims still sustained the feeling of being coerced, degrated, humiliated, threatened, intimidated, or frightened. The second and the third criteria served bullying as a subset of the broader concept of aggresion. Meanwhile, those all criteria served whether or not a negative action can be labeled as being bullied (e.g. friendly form of teasing, fight between two people with the same strengh cannot be labeled as bullying) (Thornberg \& Jungert, 2014).

In general, there are two types of roles involved in the situation, namely, the victim and the bully. In fact, reviewing on Demaray and Salmivalli's study, there are five participant roles or behaviours of bullying: the bully, assistant the bully, the victim, the 
defender of victim, and the outsider. Assistant the bully involves in supporting and encouraging the bully. The defender of victim takes role in confronting the bully and helping the victim to feel better. Outsiders are those who observe bullying but do not anything to stop or to intervene bullying (Jenkins et al., 2016). Despite each role engaged in disctinct behavior, in some studies, assistants, defenders, and outsiders are collectively called as bystanders.

The person who commit negative actionsthe bully - can be a single individual or group, and -the victim- as the target of bullying can be a single individual or group. The form of bullying can be divided into direct and indirect bullying. Direct bullying includes physical attack (e.g. hitting, kicking, punching, pushing around) and verbal abuse (e.g. threatening, mocking, name-calling); whereas, indirect bullying takes the form of social manipulation (e.g. blackmailing, spreading rumors, gossiping) or social isolation or exclusion (e.g. ignoring, avoiding verbal contact) (Meriläinen et al., 2016; Cornell \& Limber, 2015). Based on the structure of relationship, bullying can be reviewed as a vertical and horizontal phenomenon (Parzefall \& Salin, 2010). Vertical bullying takes place when the bully has a superior position than the target. This phenomenon is common in the workplace. On the other hand, horizontal bullying occurs between two persons in equal position; for instance, two students in the same year.

Having experience of bullying has very detrimental effect. Research using either cross-sectional or longitudinal approach reports that victims of bullying are indicated poor mental health, problem in academic and life outcome compared to the person who has not bullying experience (Fullchange \& Furlong, 2016). Ttofi, Farrington, \& Losel conducted a study about meta-analysis of 28 longitudinal studies found that engaging in aggressive and violent acts in later period of life was predicted by experiencing victimization in school (Fullchange \& Furlong, 2016). Swearer, et al. said that the literature and found that victims of bullying were increased likelihood of depression (Fullchange \& Furlong, 2016). In addition to depression, bullying victim in earlier period in life reported lower self-esteem, an increased of anxiety and fear of negative evaluation from others (Roth et al in Cosgrove et al., 2017). Research on bullying more put attention to the mental health of the victims; indeed, the mental health of the bully is also worse, such as immaturity, loneliness, depression, low self esteem, fear and anxiety ( Twyman, et al., 2010; Cowie \& Myers, 2014).

\section{CONCLUSION}

This study found a number of percentages of bullying in university context. This finding confirms that bullying still exists in higher education. The result of the stuy imples that bullying victims need social support from mental health professionals in handling their bullying experience since it can adversely affect their well-being in the long term.

\section{REFERENCES}

Bowes, L., Wolke, D., Joinson, C., Lereya, S. T., \& Lewis, G. (2014). Sibling Bullying And Risk of Depression, Anxiety, and Self-Harm: A Prospective Cohort Study. Pediatrics, 134(4), e1032-e1039.

Chapell, M., Casey, D., Cruz, C. D. la, Ferrell, J., Forman, J., Lipkin, R., Newsham, M., Sterling, M., \& Whittaker, S. (2004). Bullying in College by Students and Teachers. Adolescence, 39(153), 5364.

Chen, Y.Y., \& Huang, J.-H. (2015). Precollege and In-College Bullying Experiences and Health-Related Quality of Life Among College Students. Pediatrics, 135(18), 18-25.

Coleyshaw, L. (2010). The Power of Paradigms: A Discussion of The Absence of Bullying Research in The Context of The University Student Experience. Research in PostCompulsory Education, 15(4), 377-386.

Copeland, W. E., Wolke, D., Angold, A., \& Costello, E. J. (2013). Adult Psychiatric Outcomes of Bullying and Being Bullied by Peers in Childhood and Adolescence. JAMA psychiatry, 70(4), 419-426.

Cornell, D., \& Limber, S. P. (2015). Law and Policy on The Concept of Bullying at School. American Psychologist, 70(4), 333.

Cosgrove, H. E., Nickerson, A. B., \& DeLucia, 


\title{
28| PSIKOPEDAGOGIA
}

\author{
JURNAL BIMBINGAN DAN KONSELING
}

Vol.10, No.1, June 2021

J. (2017). Past Peer Victimization and Current Adult Attachment in College Students. Journal of College Counseling, 20, 22-36.

Cowie, H., \& Myers, C.A. (2014). Bullying Amongst University Students In The UK. International Journal of Emotional Education, 6(1), 66-75.

Elghazally, N. M., \& Atallah, A. O. (2020). Bullying Among Undergraduate Medical Students At Tanta University, Egypt: A Cross-Sectional Study. Libyan Journal of Medicine, 15(1).

Fullchange, A., \& Furlong, M. J. (2016). An Exploration of Effects of Bullying Victimization From A Complete Mental Health Perspective. SAGE Open.

Giovazolias, T., \& Malikiosi-Loizos, M. (2016). Bullying at Greek universities: An Empirical Study, In H. Cowie \& C.-A. Myers (Eds.), Bullying among university students: Cross-national perspectives, 110-126.

Holt, M. K., Green, J. G., Reid, G., DiMeo, A., Espelage, D. L., Felix, E. D., Furlong, M. J., Poteat, V. P., \& Sharkey, J. D. (2014). Associations Between Past Bullying Experiences and Psychosocial and Academic Functioning Among College Students. Journal of American College Health, 62(8), 552-560.

Jenkins, L. N., Demaray, M. K., Fredrick, S. S., \& Summers, K. H. (2016). Associations Among Middle School Students' Bullying Roles and Social Skills. Journal of School Violence, 15(3), 259-278.

Marraccini, M. E., Weyandt, L. L., \& Rossi, J. S. (2015). College Students' Perceptions of Professor/Instructor Bullying: Questionnaire Development and Psychometric Properties. J Am Coll Health, 63(8), 563-572.

Matsunaga, M. (2010). Individual Dispositions And Interpersonal Concerns Underlying Bullied Victims' Self-Disclosure In Japan And The US. Journal of Social \& Personal Relationships, 27, 1124-1148.

McMahon, E. M., Reulbach, U., Keeley, H., Perry, I. J., \& Arensman, E. (2012). Reprint Of: Bullying Victimisation, Self Harm And Associated Factors In Irish Adolescent Boys. Social Science \& Medicine, 74(4), 490-497.

Meriläinen, M., Sinkkonen, H.-M., Puhakka, H., \& Käyhkö, K. (2016). Bullying and Inappropriate Behaviour Among Faculty
Personnel. Policy Futures in Education 14(6), 617-34.

Olweus, D. (2013). School Bullying: Development and Some Important Challenges. Annual Review of Clinical Psychology, 9, 751-780.

Parzefall, M. R., \& Salin, D. M. (2010). Perceptions of and Reactions To Workplace Bullying: A Social Exchange Perspective. Human Relations, 63(6), 761-780.

Sinkkonen, H. M., Puhakka, H., \& Meriläinen, M. (2014). Bullying At A University: Students' Experiences Of Bullying. Studies in Higher Education, 39(1), 153-165.

Thornberg, R., \& Jungert, T. (2014). School Bullying and The Mechanisms of Moral Disengagement. Aggressive Behavior, 40(2), 99-108.

Twyman, K. A., Saylor, C. F., Saia, D., Macias, M. M., Taylor, L. A., \& Spratt, E. (2010). Bullying and Ostracism Experiences In Children With Special Health Care Needs. Journal of Developmental \& Behavioral Pediatrics, 31(1), 1-8.

Wensley, K., \& Campbell, M. A. (2012). Heterosexual and Nonheterosexual Young University Students' Involvement In Traditional and Cyber Forms Of Bullying. Cyberpsychology, Behavior \& Social Networking, 15, 649-654. 